\title{
Physical, physicochemical (technological) and chemical characteristics of common bread wheat (Triticum aestivum L.) varieties grown in Mardin region of Turkey
}

\section{Türkiye'nin Mardin yöresinde yaygın yetiştirilen ekmeklik buğday (Triticum aestivum L.) çeşitlerinin fiziksel, fizikokimyasal (teknolojik) ve kimyasal özellikleri}

\author{
Ali YILDIRIM ${ }^{1 *} \mathbb{D}$, Önder DEGER ${ }^{2} \mathbb{D}$ \\ ${ }^{1,2}$ Harran Üniversitesi, Mühendislik Fakültesi, Gıda Mühendisliği Bölümü, Osmanbey Kampüsü, Haliliye-Şanlıurfa \\ ${ }^{1}$ https://orcid.org/0000-0001-7226-1902; ${ }^{2 h t t p s: / / o r c i d . o r g / 0000-0001-9743-1728 ~}$
}

\section{To cite this article:}

Yıldırım, A. \& Deger, Ö. (2021). Physical, physicochemical (technological) and chemical characteristics of common bread wheat (Triticum aestivum L.) varieties grown in Mardin region. Harran Tarım ve Gıda Bilimleri Dergisi, 25(2): 151-162.

DOI: 10.29050/harranziraat.892966

${ }^{*}$ Address for Correspondence: Ali YILDIRIM

e-mail:

ayildirim10@gmail.com

Received Date:

08.03.2021

Accepted Date:

24.05.2021

(C) Copyright 2018 by Harran University Faculty of Agriculture. Available on-line at www.dergipark.gov.tr/harranziraat

\section{ABSTRACT}

In this study, the physical (color, grain size, equivalent diameter, sphericity, kernel surface area, kernel volume, thousand kernel weight, hectoliter weight, dry weight and wet weight), physicochemical (technological) (dry volume, wet volume, water absorption capacity, water absorption index, swelling capacity, swelling index, gluten index, Zeleny sedimentation and delayed sedimentation) and chemical (moisture, protein and wet gluten contents) properties of the most grown bread wheat varieties (Triticum aestivum L.) (Adana 99, Ceyhan 99, Sagittario, and Dinç) in Mardin region of Turkey during 2018 were compared. Statistically significant differences $(P \leq 0.05)$ were obtained between wheat varieties in terms of physical, physicochemical-technological and chemical quality characteristics. It has been determined that thousand kernel weight and hectoliter weight values of wheat varieties which are superior to the wheat varieties in terms of their grain sizes were generally higher than the others. Thousand kernel weight, hectoliter weight, protein, wet gluten, gluten index and Zeleny sedimentation values of wheat varieties were found in the range of $35.48-42.71 \mathrm{~g}$, $77.91-81.00 \mathrm{~kg} / \mathrm{hl}, 11.50-13.25 \%, 29.04-33.79 \%, 82.5-89.5$ and $26.0-43.5 \mathrm{ml}$, respectively. The differences in quality characteristics between wheat varieties may be important for the flour producers that produce flour for both industrial and traditional bread (tandoori bread and peksimet, etc.) producers, especially in the Mardin region.

Key Words: Wheat, Kernel, Bread, Quality characteristics

\section{öz}

Bu çalışmada, Türkiye'nin Mardin yöresinde 2018 döneminde en çok yetiştirilen Adana 99, Ceyhan 99, Sagittario, ve Dinç buğday çeşitleri olmak üzere 4 farklı ekmeklik buğday (Triticum aestivum L.) çeşidinin fiziksel (renk, tane boyutları, eşdeğer çap, küresellik, tane yüzey alanı, tane hacmi, bin tane ağırlığı, hektolitre ağırlığı, kuru ağılık ve yaş ağırlık), fizikokimyasal (teknolojik) (kuru hacim, ıslak hacim, su alma kapasitesi, su alma indeksi, şişme kapasitesi, şişme indeksi, gluten indeksi, Zeleny sedimantasyon ve gecikmeli sedimentasyon) ve kimyasal (nem, protein ve yaş gluten miktarları) özellikleri karşılaştırılmıştır. Buğday çeşitleri arasında fiziksel, fizikokimyasal-teknolojik ve kimyasal kalite özellikler açısından istatistiksel olarak önemli farklar $(P \leq 0.05)$ bulunmuştur. Buğday çeşitlerinden tane boyutları özellikleri bakımından üstün olan buğdayların bin tane ağırlığı ve hektolitre ağırlığı değerlerinin de genellikle diğerlerinden yüksek olduğu tespit edilmiştir. Örneklerin bin tane ağırlığı, hektolitre ağırlığı, protein, yaş gluten, gluten indeksi ve Zeleny sedimentasyon değerleri sırasıyla 35.48$42.71 \mathrm{~g}, 77.91-81.00 \mathrm{~kg} / \mathrm{hl}, \% 11.50-13.25$, \%29.04-33.79, \%82.5-89.5 ve 26.0-43.5 ml aralıklarında tespit edilmiştir. Buğday çeşitleri arasındaki kalite karakteristiklerindeki farklılıklar özellikle Mardin yöresindeki gerek endüstriyel gerekse geleneksel bazı (tandır ekmeği ve peksimet vb.) ekmek üreten un üreticileri açısından önemli olabilir.

Anahtar Kelimeler: Buğday, Tane, Ekmek, Kalite özellikleri 


\section{Introduction}

The fast rise in the world population demands parallel increases in food production, particularly of wheat. Bread wheat (Triticum aestivum L.), which is widely grown in many countries, is a major field crop and is therefore of great economic importance. Wheat is a cereal variety of the Gramineae family, without husks, with a nearly spherical oval appearance. Wheat grain is rich in carbohydrates, proteins, minerals, trace elements, vitamins, fatty acids, color substances called secondary plant metabolites and phenols. Wheat is a type of cereal that ranks first in human nutrition in the world and is cultivated almost everywhere in the World. According to the 2019 data of FAO, wheat is harvested in an area of $215,901,958$ ha with a total annual production of $765,769,635$ metric tons in the World. The harvest in Turkey in the same year was 6,831,854 ha and it was $3.2 \%$ of the World wheat harvest. The annual production of wheat in Turkey in 2019 was $19,000,000$ metric tons (FAO, 2020).

The most common consumption types of wheat are the products such as flour, bread, pasta, semolina, biscuits. Besides the commercial varieties in the World and Turkey, different traditional products are made and consumed by using local wheats. Breads produced using local varieties have become a part of Anatolian culture with the production techniques and tastes specific to the regions. In Anatolia, wheat culture is used as a raw material for many local products such as kadayif, phyllo, lavash, tandoori, kömbe, flat bread, couscous, noodles, bulgur, pasta, and keşkek, which were previously widely used in rural areas and now used in cities (Dizlek and Gul, 2009; Dizlek, 2012; FAO., 2018).

Considering the human nutrition of Turkey, the consumption of bread based on wheat is due to economic reasons and traditional habits. The amount of bread consumption varies according to these habits, and bread continues to be the most commonly consumed food today (Gül et al., 2017). The daily bread consumption was 333 grams in Turkey which is one of the most consuming countries in the world (Anonymous, 2019).

Mardin is one of the important cities in Turkey according to wheat production area, wheat varieties, the number of flour producing factories and production of local bread types. A total of 2.6 million decares of agricultural land was allocated for cereals and other crops in 2017 in Mardin, and approximately 1.5 million tons of crops were harvested. Approximately $54 \%$ of this land was wheat planted and the total production amount was 838,500 tons in 2017 (Anonymous, 2018). The most cultivated wheat varieties in Mardin were Adana 99, Ceyhan 99, Dinç and Sagittario, respectively. (Anonymous, 2018). 41 of 73 foodproducing factories in Organized Industrial Zone in Mardin have been produced flour (Anonymous, 2020).

Bread wheat quality is determined by some physical and physicochemical (technological) characteristics. These characteristics are important for both flour producers and bread producers, especially in bread types and production stages. Important quality factors in wheat and flour standards are hectoliter weight, thousand kernel weight, color, ash content, protein content, gluten content, and sodium dodecyl sulphate (SDS) sedimentation value. The physical and physicochemical characteristics (such as density, hectoliter weight, kernel size, thousand kernel weight, color, gluten index, Zeleny and modified Zeleny sedimentation values), the chemical properties (such as moisture, protein, gluten) have been studied extensively in Triticum aestivum (Khatkar et al., 2002; Gül et al., 2012; Karaman et al., 2012; Dizlek et al., 2013a, b; Kaplan-Evlice et al., 2016; Şahin et al., 2016; Aydoğan and Soylu, 2017; Gül et al., 2020; Şahin et al., 2020).

In this study, considering the needs of the flour producers in the Mardin Region of Turkey, it was aimed to determine the suitable wheat as a result of the analyzes made from the wheat purchased for commercial flour production and the obtained quality parameters. 


\section{Materials and Methods}

\section{Materials}

In this study, Adana 99, Ceyhan 99, Sagittario, and Dinç bread wheat (Triticum aestivum L.) varieties, which are mostly grown in 2017/2018 production year at Mardin region, were used as materials. Wheat samples were obtained from Kızıltepe / Mardin Wheat market. Wheat used in the experiments was first cleaned from the foreign materials and broken grains. Cold tempering process (by spraying and mixing method) was applied by adding water according to the amounts specified in AACCI method No. 2695.01 (AACCI, 2010). After the samples were tempered, they were mixed at 2 hour intervals and after 24 hours they were ground in a laboratory type mill (Serttaş machine Istanbul, Turkey). After milling the samples were sieved to $180 \mu \mathrm{m}$ particle size.

\section{Determination of physical characteristics}

Length, width and thickness of kernels

Randomly selected wheat kernels (100 kernels) were used to measure length (L), width (W) and thickness (T) using a Vernier caliper (Mutitoyo No: $505-633$, Japan).

\section{Equivalent diameter}

The equivalent diameter, $D_{e}$, was calculated using the Eq. 1 (Mohsenin, 1986).

Equalent diameter $\left(D_{e}\right)=(\mathrm{LWT})^{1 / 3}$

where, $D_{e}, L, W$ and $T$ represent the equivalent diameter $(\mathrm{mm})$, length $(\mathrm{mm})$, width $(\mathrm{mm})$ and thickness $(\mathrm{mm})$, respectively.

\section{Sphericity}

The sphericity $(\phi)$ was calculated as a function of the three principal dimensions as shown in Eq. 2 (Mohsenin, 1986).

$\phi=\frac{(\mathrm{LWT})^{1 / 3}}{\mathrm{~L}}$

where, $\phi$ is the sphericity of wheat kernels.

\section{Surface area of kernels}

The surface area, $A_{k}\left(\mathrm{~mm}^{2}\right)$, of the kernels was calculated using the Eq. 3 (Mohsenin, 1986).

Kernel surface area $\left(A_{k}\right)=\frac{\pi(\mathrm{WT})^{\frac{1}{2}} L^{2}}{\left(2 L-(\mathrm{WT})^{\frac{1}{2}}\right)}$

where, $A_{k}$ is the surface area $\left(\mathrm{mm}^{2}\right)$ of kernels. $\pi$ is the constant.

\section{Kernel volume}

The volume, $V_{k}\left(\mathrm{~mm}^{3}\right)$, of the kernels was calculated using the Eq. 4 (Mohsenin, 1986).

Kernel volume $\left(V_{k}\right)=\frac{\pi\left((\mathrm{WT})^{\frac{1}{2}}\right)^{2} L^{2}}{6(2 L-3)}$

where, $V_{k}\left(\mathrm{~mm}^{3}\right)$ is the volume of kernels.

\section{Dry weight}

One hundred wheat sample was counted and weighed. This value was recorded as dry weight (g).

\section{Wet weight}

One hundred of wheat kernels and fifty $\mathrm{ml}$ of water were taken in a graduated cylinder, and after keeping for 16 hours, the wheat kernals were dried with blotter paper and the result was recorded as gram.

\section{Thousand kernel weight}

For the determination of the thousand kernel weight, 500 wheat kernels of wheat samples were weighed and the results were multiplied by 2 . Thousand kernel weight values were recorded as grams of dry matter (Elgün et al., 2002).

\section{Hektoliter weight}

The hectoliter weight of wheat samples was measured according to AACCI method no. 5510.01 and the results were expressed in $\mathrm{kg} / \mathrm{hl}$ (AACCI, 2010).

\section{Color}

The surface color of wheat kernels was measured using Ultra Scan VIS Color Quest XE 
HunterLab (Hunter Associates Laboratory Inc., Reston, VA, USA) after being standardized using Hunter Lab colour standards and 'L* (lightness), $a *$ (redness to greenness) and $b^{*}$ (yellowness to blueness) values were measured.

Determination of physicochemical-technological characteristics

Water absorption capacity, water absorption index, dry volume, wet volume, swelling capacity, swelling index, gluten index, Zeleny sedimentation and Delayed sedimentation values of wheat samples were determined according to the methods of Youssef (1978) and Williams et al. (1983).

\section{Water absorption capacity}

The water absorption capacity (WAC) of wheat samples was calculated according to the Eqs. 5 and 6 , and the results were recorded as $\mathrm{g} /$ kernel. If there is kernels that do not swell;

$W A C\left(\frac{g}{\text { kernel }}\right)=\frac{\left[(W W-D W)-\left(\frac{D W}{100}\right) * \text { Not swollen kernels }\right]}{(100-\text { Not swollen kernels })}$

If there is no swelling kernels;

$W A C\left(\frac{g}{\text { kernel }}\right)=\frac{(W W-D W)}{100}$

where, WAC, DW and WW are water absorption capacity, dry weight, wet weight, respectively.

\section{Water absorption index}

Water absorption index (WAI) of wheat samples was calculated according to the Eq. 7, and the results were recorded as $(\%, w / w)$.

$W A I(\%, g / g))=\frac{(\text { Water absorption capacity })}{\text { Dryweight } / 100}$

\section{Dry volume}

$50 \mathrm{ml}$ of distilled water was added to $100 \mathrm{ml}$ graduated cylinder and 100 kernels of wheat samples were added. The difference between the final volume and the first volume before wheat was added was calculated, and the result was recorded as $\mathrm{ml}$.

\section{Wet volume}

$50 \mathrm{ml}$ of distilled water was added to a graduated cylinder, and 100 kernels of wheat samples were added. After waiting for $16 \mathrm{~h}$, the wheat samples were dried with a paper towel. $100 \mathrm{ml}$ of distilled water was poured into the cylinder and then dried wheat was added. The difference between the final volume and the initial volume before wheat was added was calculated and the result was recorded as $\mathrm{ml}$.

\section{Swelling capacity}

The swelling capacity of wheat samples was calculated according to the Eq. 8 and the result was recorded as $\mathrm{ml} /$ kernel.

$$
S C\left(\frac{m l}{\text { kernel }}\right)=\frac{[(W V-100)-(D V-50)]-\left(\frac{D V-50}{100}\right) * \text { Not swollen kernels }}{100-\text { Not swollen kernels }}
$$

where, SC, WV and DV are swelling capacity, wet volume and dry volume, respectively.

\section{Swelling index}

The swelling index of wheat samples was calculated according to the Eq. 9 and the result was recorded as in $(\%, w / w)$.

Swelling index $\left(\%, \frac{w}{w}\right)=\frac{\text { Wet volume }-100}{\text { Dry volume }-50}$

\section{Gluten index}

The gluten index of the samples was determined by the approved AACCI method no. 38-12.02 and the results were found as $\%(w / w)$ (AACCI, 2010).

\section{Zeleny sedimentation test}

The Zeleny sedimentation value of the samples was determined by the standard methods of International Assocation for Cereal Science and Technology (ICC) number 116 (ICC, 2002).

\section{Delayed Zeleny sedimentation test}

Delayed sedimentation values of samples was determined according to the method made by Greenaway et al. (1965). The difference was found by comparing the Zeleny sedimentation value with the Delayed Zeleny sedimentation value. If this difference exceeds more than $5 \mathrm{ml}$, it 
indicates that the wheat has been damaged by sunn pest. Standard hydration time (5 $\mathrm{min}$ ) in Zeleny sedimentation was extended to $120 \mathrm{~min}$ in Delayed Zeleny sedimentation (Dizlek and İslamoğlu, 2015).

\section{Determination of chemical properties}

\section{Moisture content}

Moisture content of wheat varieties was determined by the approved AACCI method no.44-15.02 (AACCI, 2010).

\section{Protein content}

Protein content of wheat varieties was determined by the approved $A A C C$ method no. 46-10.01 using the Kjeldahl method and expressed using the conversion factor $\mathrm{N} \times 5.7$ (AACCI, 2010).

\section{Wet gluten}

The wet gluten of the samples was determined by the approved AACCI method no. 38-12.02 and the results were found as $\%(w / w)$ (AACCl, 2010).

\section{Statistical analysis}

Analysis of variance (ANOVA) followed by
Duncan's multiple range test were performed using the SPSS 22 (SPSS Inc., Chicago, IL, USA). All the calculations were done at the significance level of $P \leq 0.05$. Each analysis was performed in triplicate.

\section{Results and Discussion}

\section{Physical characteristics of bread wheat varieties}

Physical characteristics such as length (L), width $(W)$, thickness $(T)$, equvalent diameter $\left(D_{e}\right)$, sphericity $(\phi)$, kernel volume $\left(V_{k}\right)$, kernel surface area $\left(A_{k}\right)$, color values $\left(L^{*}, a^{*}\right.$ and $\left.b^{*}\right)$ of the common bread wheat varieties grown in Mardin region of Turkey were determined to assess their contribution to the quality of the millers in Mardin. The results of these properties were given in Table 1 . Length, width, thickness and equivalent diameter are commonly used measures of size. The differences between length, width, thickness, equivalent diameter, sphericity, kernel volume, kernel surface area, color values $\left(L^{*}, a^{*}\right.$ and $\left.b^{*}\right)$ of wheat varieties were found to be statistically significant $(P \leq 0.05)$ (Table 1$)$.

Table 1. Physical characteristics of bread wheat varieties

\begin{tabular}{|c|c|c|c|c|c|c|c|c|c|c|}
\hline \multirow[b]{2}{*}{ Variety } & \multirow{2}{*}{$\begin{array}{r}\mathrm{L} \\
(\mathrm{mm})\end{array}$} & \multirow{2}{*}{$\begin{array}{r}W \\
(\mathrm{~mm})\end{array}$} & \multirow{2}{*}{$\begin{array}{r}\mathrm{T} \\
(\mathrm{mm})\end{array}$} & \multirow{2}{*}{$\begin{array}{r}D_{e} \\
(\mathrm{~mm})\end{array}$} & \multirow{2}{*}{$\begin{array}{r}V_{k} \\
\left(\mathrm{~mm}^{3}\right)\end{array}$} & \multirow{2}{*}{$\begin{array}{r}A_{k} \\
\left(\mathrm{~mm}^{2}\right)\end{array}$} & \multicolumn{4}{|c|}{ Color values } \\
\hline & & & & & & & $\phi$ & $\mathrm{L}^{*}$ & a* & $b^{*}$ \\
\hline \multirow{2}{*}{ Adana99 } & 6.63 & 3.27 & 2.97 & 4.01 & 21.79 & 42.43 & 0.61 & 56.80 & 7.45 & 20.81 \\
\hline & $\pm 0.01^{d}$ & $\pm 0.07^{b}$ & $\pm 0.03^{c}$ & $\pm 0.05^{b c}$ & $\pm 0.02^{d}$ & $\pm 0.04^{d}$ & $\pm 0.02^{b}$ & $\pm 0.04^{c}$ & $\pm 0.07^{a}$ & $\pm 0.02^{d}$ \\
\hline \multirow{2}{*}{ Ceyhan99 } & 6.31 & 3.14 & 2.84 & 3.83 & 19.33 & 38.77 & 0.61 & 54.95 & 7.23 & 19.22 \\
\hline & $\pm 0.05^{b}$ & $\pm 0.10^{\mathrm{ab}}$ & $\pm 0.01^{b}$ & $\pm 0.12^{\mathrm{ab}}$ & $\pm 0.04^{b}$ & $\pm 0.02^{b}$ & $\pm 0.02^{b c}$ & $\pm 0.03^{b}$ & $\pm 0.04^{\mathrm{a}}$ & $\pm 0.04^{b}$ \\
\hline \multirow{2}{*}{ Dinç } & 6.11 & 3.30 & 2.91 & 3.89 & 20.36 & 39.85 & 0.64 & 54.50 & 7.54 & 20.55 \\
\hline & $\pm 0.02^{\mathrm{a}}$ & $\pm 0.03^{b}$ & $\pm 0.02^{b c}$ & $\pm 0.01^{\mathrm{ab}}$ & $\pm 0.01^{\mathrm{c}}$ & $\pm 0.03^{c}$ & $\pm 0.02^{c}$ & $\pm 0.07^{b}$ & $\pm 0.03^{a}$ & $\pm 0.06^{c}$ \\
\hline \multirow{2}{*}{ Sagittario } & 6.56 & 2.99 & 2.68 & 3.74 & 17.84 & 37.19 & 0.57 & 52.78 & 6.89 & 16.27 \\
\hline & $\pm 0.03^{c}$ & $\pm 0.10^{\mathrm{a}}$ & $\pm 0.04^{\mathrm{a}}$ & $\pm 0.07^{a}$ & $\pm 0.03^{\mathrm{a}}$ & $\pm 0.01^{\mathrm{a}}$ & $\pm 0.01^{\mathrm{a}}$ & $\pm 0.05^{a}$ & $\pm 0.05^{a}$ & $\pm 0.03^{a}$ \\
\hline
\end{tabular}

Means with different superscripts within a column are significantly different at $\mathrm{P}<0.05$. L: length, W: width, T: Thickness, De: equalent diameter, Vk: Kernel volume, Ak: kernel surface area, $\phi$ : Sphericity

Shape and size is an important physical properties of kernels in heat and mass transfer calculations, screening solids to separate foreign materials, and evaluating the quality of food materials. The shape of a food material is usually expressed in terms of its sphericity. Sphericity is an expression of a shape of a solid relative to that of a sphere of the same volume. It was determined that the length, width, thickness, equivalent diameter and sphericity of wheat varieties varied between 6.11-6.63 mm, 2.99-3.30 $\mathrm{mm}, 2.68-2.97 \mathrm{~mm}, 3.74-4.01 \mathrm{~mm}$ and 0.57-064. The highest length value was found in Adana 99 wheat variety, while the lowest was found in Dinç 
wheat variety. The lowest values in terms of width, thickness, equivalent diameter and sphericity were found in Sagittario wheat variety (Table 1).

The highest width value was found in Dinç wheat variety. The thickness and equivalent diameter of Adana 99 wheat have been found the highest. The highest sphericity value was found in Dinç wheat variety. In a study for 5 different wheat varieties grown in Turkey, the length, width, thickness, equivalent diameter and sphericity range values were found to be 6.24$7.43 \mathrm{~mm}, 2.71-3.30 \mathrm{~mm}, 2.62-3.06 \mathrm{~mm}, 3.57-$ $4.11 \mathrm{~mm}$ and 0.53-060, respectively (Kalkan and Kara, 2011). The sphericity of 5 different wheat varieties were found to be in the range of 0.48 0.65 (Tabatabaeefar, 2003). In a study conducted on 16 varieties of wheat grown in Southern Italy, the length, width and thickness range values were found to be $6.39-7.83 \mathrm{~mm}, 2.17-3.31 \mathrm{~mm}$ and 2.66-3.05 mm, respectively (Troccoli and Di Fonzo, 1999). A previous study on some wheat varieties was also showed similar conclusions (Yıldırım and Atasoy, 2020). Kernel size uniformity is very important in wheat milling industry, especially in cleaning, conditioning, debranning or grinding processes. High-quality bread wheat is expected to have larger kernels with vitreous endosperm in order to obtain flour with higher yield and brightness (Dziki and Laskowski, 2005). Kernel shape (Lenght, width, thickness and diameter) may depend- not only on wheat genus or species but also on wheat variety and agroclimatic conditions. It is evident from the physical data that wheat varieties in this study were of adequate kernel size for flour milling and bread processing.

Bread wheat kernels are generally white, light yellow, yellow red, amber and brown color. The color of bread wheat is especially important for bread products. $L^{*}$ values ranged between 52.78 and 56.80, and Adana 99 variety was found to be brighter than other varieties while there was a significant difference between wheat varieties $(P \leq 0.05)$ in terms of $L^{*}$ values. There was no statistically significant difference ( $P>0.05$ ) between wheat varieties in terms of $a^{*}$ values. Considering the $b^{*}$ values, it can be said that Adana 99, Ceyhan 99 and Dinç wheat varieties are closer to each other and more yellowish, however, it has been determined that Sagittario wheats are darker and reddish than others. Bayrakcı (2008) reported that the $L^{*}, a^{*}$ and $b^{*}$ values of some wheat varieties varied between 55.24-60.63, 4.90-6.43 and 17.78-21.70, respectively. Yıldırım and Atasoy (2020) was found $L^{*}, a^{*}$ and $b^{*}$ values between 44.02-53.50, 5.97-7.89 and 14.96-20.24 for 6 different wheat varieties, respectively.

Physicochemical and technological characteristics of wheat varieties

Average of some physicochemicaltechnological properties of bread wheat varieties such as average dry weight, wet weight, water absorption capacity, water absorption index, dry volume, wet volume, swelling capacity, swelling index, thousand kernel weight, hectoliter weight are given in Table 2. Considering the results of these properties of the wheats, a statistically significant difference $(P \leq 0.05)$ was found between the varieties for all values.

Average dry weight values were found between $3.69 \mathrm{~g}$ and $3.90 \mathrm{~g}$. The average wet weight values were varied between $5.02 \mathrm{~g}$ and $5.45 \mathrm{~g}$, with the highest value in Adana 99 (5.45 g) and the lowest value in Sagittario wheat $(5.02 \mathrm{~g})$. The water absorption capacities of Adana 99, Ceyhan 99, Dinç and Sagittario wheat varieties were found to be $0.04,0.03,0.02$ and 0.01 $\mathrm{g} /$ kernel, respectively. It was observed that there was a proportional relationship between wet weight and water absorption capacity of wheats.

Dry volume, wet volume, swelling capacity, swelling index, thousand kernel weight and hectoliter weight values were found to be significantly different $(P \leq 0.05)$ between wheat varieties. Average dry volume was ranged between the lowest Dinç wheat with $52.0 \mathrm{ml}$ and the highest Ceyhan 99 wheat with $55.5 \mathrm{ml}$. The wet volume values were found to be close to each other between $104.5 \mathrm{ml}$ and $106.5 \mathrm{ml}$. Swelling 
capacity varied between 1.0 and $3.0 \mathrm{ml} /$ kernel. Sagittario wheat variety was the least swollen, while Adana 99 was the most swollen wheat variety.

Table 2. Physicochemical characteristics of wheat varieties

\begin{tabular}{lllllllllll}
\hline Variety & DW & WW & WAC & WAI & DV & WV & SC & SI & TKW & HLW \\
\hline \multirow{3}{*}{ Adana 99 } & 3.90 & 5.45 & 0.04 & 0.41 & 53.50 & 106.50 & 3.00 & 2.25 & 38.50 & 81.00 \\
& $\pm 0.01^{\mathrm{b}}$ & $\pm 0.06^{\mathrm{bc}}$ & $\pm 0.001^{\mathrm{c}}$ & $\pm 0.01^{\mathrm{a}}$ & $\pm 0.02^{\mathrm{b}}$ & $\pm 0.03^{\mathrm{c}}$ & $\pm 0.02^{\mathrm{d}}$ & $\pm 0.04^{\mathrm{bc}}$ & $\pm 0,05^{\mathrm{d}}$ & $\pm 0.03^{\mathrm{d}}$ \\
& 3.80 & 5.26 & 0.03 & 0.40 & 55.50 & 106.50 & 2.50 & 1.88 & 37.62 & 77.91 \\
Ceyhan 99 & $\pm 0.02^{\mathrm{ab}}$ & $\pm 0.36^{\mathrm{b}}$ & $\pm 0.002^{\mathrm{a}}$ & $\pm 0.02^{\mathrm{a}}$ & $\pm 0.03^{\mathrm{d}}$ & $\pm 0.01^{\mathrm{c}}$ & $\pm 0.01^{\mathrm{c}}$ & $\pm 0.02^{\mathrm{b}}$ & $\pm 0.02^{\mathrm{b}}$ & $\pm 0.01^{\mathrm{a}}$ \\
& 3.73 & 5.18 & 0.02 & 0.48 & 52.00 & 104.50 & 2.00 & 1.23 & 35.48 & 79.69 \\
Dinç & $\pm 0.03^{\mathrm{a}}$ & $\pm 0.09^{\mathrm{ab}}$ & $\pm 0.005^{\mathrm{b}}$ & $\pm 0.04^{\mathrm{b}}$ & $\pm 0.01^{\mathrm{a}}$ & $\pm 0.04^{\mathrm{a}}$ & $\pm 0.03^{\mathrm{b}}$ & $\pm 0.03^{\mathrm{ab}}$ & $\pm 0.01^{\mathrm{c}}$ & $\pm 0.04^{\mathrm{b}}$ \\
& 3.69 & 5.02 & 0.01 & 0.44 & 54.50 & 105.50 & 1.00 & 1.18 & 42.71 & 80.24 \\
Sagittario & $\pm 0.02^{\mathrm{a}}$ & $\pm 0.11^{\mathrm{a}}$ & $\pm 0.003^{\mathrm{d}}$ & $\pm 0.03^{\mathrm{bc}}$ & $\pm 0.02^{\mathrm{c}}$ & $\pm 0.02^{\mathrm{b}}$ & $\pm 0.02^{\mathrm{a}}$ & $\pm 0.05^{\mathrm{a}}$ & $\pm 0.02^{\mathrm{a}}$ & $\pm 0.02^{\mathrm{c}}$ \\
\hline
\end{tabular}

Means with different superscripts within a column are significantly different at $\mathrm{P}<0.05$. DW: Dry weight (g), WW: Wet weight (g), WAC: Water absorption capacity $\left(\mathrm{g}\right.$. Kernel $\left.{ }^{-1}\right)$, WAl: Water absorption index (\%, w/w), DV: Dry volume (ml), WV: wet volume (ml), SC: Swelling capacity $\left(\mathrm{ml}^{\mathrm{K}} \mathrm{Kernel}^{-1}\right)$, SI: Swelling index $(\%, \mathrm{w} / \mathrm{w})$, TKW: Thousand kernel weight $(\mathrm{g})$, HLW: Hectoliter weight $\left(\mathrm{kg} . \mathrm{hL}^{-1}\right)$.

Thousand kernel weight, which gives information about the seed and flour yield of the wheat, was varied between 35.48-42.71 g. Sagittario wheat variety had the highest thousand kernel weight value. Hectoliter weight is an important parameter used in wheat standards and commercial classification of wheats (Ünal, 2002). One of the factors that are based on the quality classification of wheat is the hectoliter weight and the higher the hectoliter weight, the greater the amount of dry matter and thus the flour yield (Manley et al., 2009). It depends on the grain size, shape, hardness or softness and density of wheat. The difference between the varieties was found to be significant in terms of hectoliter weight $(P \leq 0.05)$. The highest hectoliter weight was found to be for Adana 99 with 81.00 $\mathrm{kg} / \mathrm{hl}$ and the lowest one was found for Ceyhan 99 wheat variety with $77.69 \mathrm{~kg} / \mathrm{hl}$. Hectoliter weight up to $82.00 \mathrm{~kg} / \mathrm{hl}$ has been classified as very good wheat varieties (Diepenbrock et al., 2005). Wheat varieties with a hectoliter weight higher than $78,00 \mathrm{~kg} / \mathrm{hl}$ were classified as first class wheat according to the Wheat Standard of the Turkish Standard Institute (Anonymous, 2001). Hectoliter weight may vary depending on genetic structure, environmental conditions and cultural practices (Protic et al., 2007). Four bread wheat varieties in this study showed good values in terms of hectoliter weight and are comparable with the results of the study reported by Aktaş et al. (2011), Kılıç et al. (2012), Türk (2013), Migliorini et al. (2016), and Mutlu and Taş (2020).

The gluten index (GI) is a measurement of wheat protein that provides a simultaneous determination of gluten quality. The gluten index is used to determine whether gluten structure is weak or strong (AACCI, 2010). When the gluten index values were examined, the highest value was found in Adana 99 variety with $89.50 \%$ and the lowest value was found in Dinç wheat variety with $82.50 \%$ (Table 3). Menderis et al. (2008) reported that if the gluten index value of wheat was less than $63 \%$, gluten quality was low, between \%63-80 gluten quality was medium, between \%80-96 gluten quality was good, and higher than \%96, gluten quality was grouped as having very strong quality. According to this grouping, all varieties have been found to be in the good protein group wheats. In addition, it has been determined that the variety of bread wheats used in this study had gluten index value between the range of previous studies (Migliorini et al., 2016; Kaplan-Evlice et al., 2016). 


\begin{tabular}{|c|c|c|c|c|c|c|}
\hline Variety & $\begin{array}{l}\text { Moisture } \\
(\%, w / w)\end{array}$ & $\begin{array}{r}\text { Protein } \\
(\%, w / w)\end{array}$ & $\begin{array}{r}\text { Wet gluten } \\
(\%, w / w)\end{array}$ & $\begin{array}{r}\text { Gluten } \\
\text { index } \\
(\%, w / w)\end{array}$ & $\begin{array}{r}\text { Zeleny } \\
\text { Sedimentation } \\
(\mathrm{ml})\end{array}$ & $\begin{array}{r}\text { Delayed } \\
\text { Sedimentation } \\
(\mathrm{ml})\end{array}$ \\
\hline & 8.85 & 11.50 & 29.04 & 89.50 & 26.00 & 35.50 \\
\hline \multirow[t]{2}{*}{ Adana 99} & $\pm 0.01^{\mathrm{a}}$ & $\pm 0.05^{\mathrm{a}}$ & $\pm 0.03^{a}$ & $\pm 0.06^{d}$ & $\pm 0.02^{\mathrm{a}}$ & $\pm 0.15^{a}$ \\
\hline & 9.00 & 12.90 & 33.65 & 88.50 & 38.50 & 55.50 \\
\hline \multirow[t]{2}{*}{ Ceyhan 99} & $\pm 0.02^{b}$ & $\pm 0.04^{c}$ & $\pm 0.05^{c}$ & $\pm 0.03^{c}$ & $\pm 0.04^{c}$ & $\pm 0.22^{c}$ \\
\hline & 9.70 & 12.20 & 31.50 & 82.50 & 30.50 & 38.00 \\
\hline \multirow[t]{2}{*}{ Dinç } & $\pm 0.03^{d}$ & $\pm 0.03^{b}$ & $\pm 0.04^{b}$ & $\pm 0.01^{\mathrm{a}}$ & $\pm 0.05^{b}$ & $\pm 0.04^{\mathrm{b}}$ \\
\hline & 9.65 & 13.25 & 33.79 & 85.00 & 43.50 & 58.00 \\
\hline Sagittario & $\pm 0.01^{c}$ & $\pm 0.02^{d}$ & $\pm 0.01^{d}$ & $\pm 0.02^{b}$ & $\pm 0.07^{d}$ & $\pm 0.07^{d}$ \\
\hline
\end{tabular}

Means with different superscripts within a column are significantly different at $\mathrm{P}<0.05$.

Zeleny sedimentation test is the measurement of the settling amount of the swollen particles in a certain time in the suspension prepared with flour and lactic acid solution according to the gluten amount and quality. It is used to predict the quantity and quality of gluten, as well as to estimate the protein content of wheat with the same gluten quality (Dizlek and İslamoğlu, 2015). In wheat with high gluten content and good quality, the particles can be swollen too much due to decrease in their density and slower the settling to the bottom. Thus, the sedimentation value could have been higher. The proteolytic enzymes that sunn pest (Eurygaster spp.), Aelia spp. and Nysius huttoni leaved on the wheat grain cause the gluten proteins to break down under appropriate conditions. As a result of proteolytic enzyme activity, gluten is broken down and delayed Zeleny sedimentation value is lower than Zeleny sedimentation value. As the difference increases, it is understood that the sunn pest, Nysius huttoni damage also increases.

The lowest Zeleny sedimentation and delayed sedimentation values were determined in Adana 99, the highest Zeleny sedimentation and delayed sedimentation values were determined in Sagittario wheat variety, and statistically significant differences $(P \leq 0.05)$ were found between the varieties. It has been reported that those with a sedimentation value of $15 \mathrm{ml}$ or less are weak, between 15-24 $\mathrm{ml}$ are medium, between 25-36 ml are good and with $36 \mathrm{ml}$ and above have very good gluten quality (Elgün et al., 2002). According to this classification, it is seen that all wheat varieties have good and very good gluten quality. Türk (2013) reported that Zeleny sedimentation and delayed sedimentation values of 12 different wheat varieties was varied between 21.33-41.00 ml and 27.67-54.00 ml, respectively. Sedimentation values are considered to be poor for $15-20 \mathrm{ml}$, moderate for $20-25 \mathrm{ml}$, and suitable for bread making if it is between 25 $30 \mathrm{ml}$ (Ünal, 2003). The Zeleny sedimentation volume of different wheat varieties varied between 12.0 and $56.0 \mathrm{ml}$ (Menderis et al., 2008; Kılıç et al., 2012; Kaya and Akcura, 2014; Katyal et al., 2016; Keçeli et al., 2017; Pekmez, 2018).

\section{Chemical characteristics of bread wheat varieties}

Significant differences between bread wheat varieties $(P \leq 0.05)$ were obtained in terms of moisture content, protein content, wet gluten content (Table 3). Moisture contents of wheats have been varied between $8.85 \%$ and $9.70 \%$ and the lowest value was found in Adana 99 variety, the highest value was found in Dinç variety with $9.70 \%$, and any variety of critical moisture level did not exceed 14\% (Ünal, 2002). The differences in moisture content of wheat varieties may be due to their different chemical components as well to the shape of kernels, kernel covering structures, pre-harvest climatic conditions and storing conditions. In some studies, this effect was also confirmed that taking attention both to the genetic characters of each variety and the environment including climate and agro-factors during vegetation (Khan et al., 2009).

Bread making quality is highly dependent on the amount and quality of the protein in modern bread wheat varieties. The protein content of the 
wheat varies between 6-20\% partly depending on the type and variety but mostly depending on the soil and environmental factors of the place where it is grown (Özkaya and Özkaya, 2005). Among the wheat varieties, the highest protein content was found in Sagittario and the lowest in Adana 99. Protein content was found to be 11.50, 12.90, 12.20 and 13.25 (\%,w/w) for Adana 99, Ceyhan 99, Dinç and Sagittario, respectively (Table 3). These results are in agreement with the results of bread wheats reported by Yağdı (2004), Menderis et al. (2008), Tayyar (2010), Zilic et al. (2011), Kılıç et al. (2012), Şanal et al. (2012), Kaplan-Evlice et al. (2016) and Katyal et al. (2016).

Gluten is a group of proteins, especially wheat, responsible for the strong structure of dough. Gluten, which is an important indicator of the bread quality of wheat, is the elastic protein that shows the suitability of flour for bread making. Among the quality components of wheat, gluten plays the most important role in determining industrial use, and therefore gluten strength is one of the parameters used in the classification of wheat for bread use (Dizlek et al., 2006; Modenes et al., 2009). Wet gluten values have been varied between $29.04-33.79 \%$, and the highest value was found in Sagittario wheat variety (Table 3). Menderis et al. (2008) reported that if the wet gluten content of wheat was less than $20 \%$, gluten quality was low, between $20-27 \%$ gluten quality was medium, between $28-35 \%$ gluten quality was good, and higher than $35 \%$ gluten quality was high. Accordingly, the wet gluten values obtained in this study can be evaluated in the good gluten quality class for all bread wheat varieties. Wet gluten values for different types of bread wheat were found similar to those of this study by some researchers (Yağdı, 2004; Cristina et al., 2014; Kaplan-Evlice et al., 2016).

\section{Conclusions}

Based on the findings of this study, it was seen that there were differences between the wheat varieties with statistical significance $(P \leq 0.05)$ in terms of physical, chemical and physicochemical (technological) quality characteristics. All wheat varieties in this study showed good values in terms of all quality characteristics studied. It has been determined that the all quality values of Adana 99 wheat variety are generally superior among the most grown wheat varieties in the Mardin region of Turkey in 2017/2018. The longest wheat variety was Adana 99, while the shortest was Dinç wheat variety. The lowest values in terms of width, thickness, equivalent diameter and sphericity were found in Sagittario wheat variety. The widest was Dinç wheat variety. The thickness and equvalent diameter of Adana 99 wheat have been found the highest and the highest sphericity value was found in Dinç wheat variety. The $b^{*}$ values of Adana 99 was found to be higher than that of other wheat kernels due to bran and characteristics of variety. Sagittario wheat variety was the highest in terms of thousand kernel weight value while Adana 99 was the highest in terms of hectolitre weight value. Swelling capacity of wheat varieties varied between 1.0 and $3.0 \mathrm{ml} /$ kernel. Sagittario wheat variety was the least swollen, while Adana 99 was the most swollen wheat variety. On the other hand, Adana 99 variety had the highest value in terms of gluten index value, while Sagittario variety had the highest value in terms of wet gluten, zeleny sedimentation and delayed sedimentation values. Four wheat varieties studied had strong gluten because the values of gluten index of all varieties were higher than 80 . Considering the above analysis results, flour producers will be able to produce flour with better quality flour and suitable flour blends for different traditional breads.

\section{Acknowledgements}

This study was made from the master's thesis of Önder DEGER. The abstract of this study was published in the proceeding of $4^{\text {th }}$ International Congress on Nutrition Obesity and Community Health at 19-20 May 2021 in Istanbul. 
Conflict of Interest: The authors declare that they have no conflict of interest.

Authors' Contributions: Ö. Deger and A.Yıldırım substantially contributed to the conception and design of the article. Data curation and analysis were maintained by Ö. Deger and A.Yıldırım. Writing the entire manuscript was done by Ö. Deger and A.Yıldırım. Both authors have read, revised, and approved the manuscript.

\section{References}

AACCI. (2010). Approved Methods of the American Association of Cereal Chemists. AACCl Method 2695.01, 38-12.02, 44-15.02, 46-10.01 and 55-10.01. Approved Methods of Analyses 11th Edition, The Association: St. Paul, MN.

Aktaş, H, Kılıç, H, Kendal, E, Tekdal, S, Kahraman, M, Altıkat, A. (2011). Diyarbakır koşullarında bazı ekmeklik (Triticum aestivum L.) buğday genotiplerinin verim ve kalite bakımından değerlendirilmesi. Uluslararası Katılımlı I. Ali Numan Kıraç Tarım Kongresi ve Fuarı. 27-30 Nisan 2011, Eskisehir, 2273-2283.

Anonymous, (2001). Turkish standards. Wheat standard. TS standard no: 2974.

Anonymous, http://tuik.gov.tr/PreHaberBultenleri.do?id=27635. ErişimTarihi: 30.09.2019

Anonymous, http://www.tmo.gov.tr/Upload/Document/ekmek/t mobrosuryeni2.pdf. Erişim Tarihi:03.01.2020

Anonymous, http://www.mardinosb.org.tr/web/Detay.php?Detay Goster $=727 \&$ Kat $=75$. Erişim Tarihi: 03.01.2020

Aydoğan, S. and Soylu, S. (2017). Ekmeklik buğday çeşitlerinin verim ve verim öğeleri ile bazı kalite özelliklerinin belirlenmesi. Tarla Bitkileri Merkez Araştırma Enstitüsü Dergisi, 26 (1), 24-30.

Bayrakcı, H.A. (2008). Buğdayın Tavlanmasında Mikrodalga Uygulamasının Ögütme ve Ekmekçilik Kalitesine Etkisi Üzerine Bir Araştırma. Selçuk Üniversitesi, Fen Bilimleri Enstitüsü, Gıda Mühendisliği Anabilim Dalı, Yüksek Lisans Tezi, Konya, 94s.

Cristina, M.F., Ferrari, M.C., Clerici, M.T.P.S. and Chang, Y.K. (2014). A comparative study among methods used for wheat flour analysis and for measurements of gluten properties using the Wheat Gluten Quality Analyser (WGQA). Food Science and Technology (Campinas), 34 (2), 235-242.

Diepenbrock, W., Ellmer, F. and Leon, J. (2005). Ackerbau, Pflanzenbau und Pfl anzenzüchtung. Stuttgart, Germany, Verlag Eugen Ulmer, Stuttgart.

Dizlek, H. (2012). Buğdaydaki gluten proteinlerinin diğer un ve hamur bileşenleriyle etkileşimleri. Dünya Gıda Dergisi, 18(1), 42-48.

Dizlek, H. and Gül, H. (2009). Required criteria for the definition of bread attributes I. Miller, 16, 56-65.
Dizlek, H. and İslamoğlu, M. (2015). Effects of sunn pest (Eurygaster maura L) heteroptera scutelleridae sucking number on physical and physicochemical characteristics of wheat varieties. Journal of Applied Botany and Food Quality, 88, 10-15.

Dizlek, H., Gül, H., Özer, M.S., Aksoy, M. ve Özkan, H. (2013a). Çukurova üniversitesi ziraat fakültesi tarla bitkileri bölümü tarafından yetiştirilen 30 farklı ekmeklik buğday çeşidinin değerlendirilmesi I. Fiziksel ve teknolojik özellikler. Dünya Gıda Dergisi, 18(1), 76-88.

Dizlek, H., Özer, M.S., Altan, A. and Gül., H. (2006). Buğdaydaki gluten proteinlerinin birbirleriyle etkileşimleri, Hububat Ürünleri Teknolojisi Kongresi, 7-8 Eylül 2006, Gaziantep, s:280-286.

Dizlek, H., Özer, M.S., Gül, H., Dizlek, E. ve Özkan, H. (2013b). 2002-2003 Ürün yılında çukurova üniversitesi tarla bitkileri bölümü arazilerinde yetiştirilen 24 farklı buğday çeşidinin kalitatif özelliklerinin belirlenmesi. Gıda Teknolojileri Elektronik Dergisi, 8(3), 34-50.

Dziki, D. and Laskowski, J. (2005). Wheat kernel physical properties and milling process. Acta Agrophysica, 6, 59-71.

Elgün, A., Certel, M., Ertugay, Z. ve Kotancılar, H.G. (2002). Tahıl ve ürünlerinde analitik kalite kontrolü ve laboratuvar uygulama klavuzu, Atatürk Üniversitesi Yayın No: 867, Ziraat Fakültesi Yayın No: 335, Ders Kitapları Seri No: 82, Atatürk Üniversitesi Ziraat Fakültesi Ofset Tesisi, Erzurum, 283s.

FAO. (2018). Biodiversity of Turkey: Contribution of genetic resources to agricultural and food system. Ankara: FAO.

FAO. (2019). Food and Agricultural Commodities Production. World Wheat Production and Harvesting Area in 2018, http://faostat.fao.org. May 10, 2020.

Gül H., Kart M.F., Gül M., Akpınar M. G. (2017). Bakery products consumption and consumers' awareness in urban areas of Isparta city, Turkey. Scientific Papers Series Management, Economic Engineering in Agriculture and Rural Development, 17(2), 137-146.

Gül, H, Kara, B, Acun, S, Öztürk, A, Türk Aslan, S. (2020). Türkiye'nin göller bölgesi'nde yetiştirilen farklı buğday çeşitlerinin bazı kalite özellikleri. Türk Tarım ve Doğa Bilimleri Dergisi, 7(3), 586-595. DOI: 10.30910/turkjans.663641

Gül, H., Acun, S., Türk, S., Öztürk, A., Kara, B. (2012). Göller bölgesi'nde yetiştirilen bazı buğday çeşitlerinin fiziksel özellikleri. Batı Akdeniz Tarımsal Araştırma Enstitüsü Derim Dergisi, 29(2), 21-32.

ICC. (2002). International Association for Cereal Science and Technology. ICC-Standard No:116, Printed By ICCVienna, Edition.

Kalkan, F. and Kara, M. (2011). Handling, frictional and technological properties of wheat as affected by moisture content and cultivar. Powder Technology, 213, 116-122.

Kaplan-Evlice, A., Pehlivan, A., Külen, S., Keçeli, A., Şanal, T., Karaca, K. and Salantur, A. (2016). Ekmeklik buğday (Triticum aestivum L.) genotiplerinde ekmek hacmi ve bazı kalite parametreleri arasındaki ilişkilerin incelenmesi. Tarla Bitkileri Merkez Araştırma Enstitüsü Dergisi, 25(special issue-1), 12-18. 
Karaman, M., Kendal, E., Aktaş, H., Tekdal, S. and Altikat, A. (2012). Kalite parametreleri yönünden yerli ve yabancı bazı ekmeklik buğday çeşitlerinin değerlendirilmesi. Tarım Bilimleri Araştırma Dergisi, 5(2), 29-32.

Katyal, M., Virdi, A.S., Kaur, A., Singh, N., Kaur, s., Ahlawat, A.K. and Singh, A.M. (2016). Diversity in quality traits amongst Indian wheat varieties I: Flour and protein characteristics. Food Chemistry, 194, 337-344.

Kaya, Y. and Akcura, M. (2014). Effects of genotype and environment on grain yield and quality traits in bread wheat (Triticum aestivum L.). Food Science and Technology (Campinas), 34(2), 386-393.

Keçeli, A., Kaplan-Evlice, A., Pehlivan, A., Şanal, T., Karaca, K., Külen, S., Seis-Subaşı, A., Salanturksu, A. (2017). Ekmeklik buğdayda (Triticum aestivum L.) zeleny sedimantasyon analizi ve diğer kalite paramatreleri ile ilişkisinin incelenmesi. Journal of Nature and Science, 20, 292-296.

Khan, M. R., F. M. Anjum, T. Zahoor and H. Nawaz. (2009). Biochemical and technological characterization of pakistani spring wheats. Pakistan Journal of Agriculture and Science, 46(4), 271-279.

Khatkar, B.S., Fido, R.J., Tatham, A.S. \& Schofield, J.D. (2002). Functional properties of wheat gliadins. I. Effects on mixing characteristics and bread making quality. Journal of Cereal Science, 35, 299-306.

Kılıç, H., Aktas, H., Kendal, E. and Tekdal, S. (2012). İleri kademe ekmeklik buğday (Triticum aestivum L.) genotiplerinin biplot analiz yöntemi ile değerlendirilmesi. Türk Doğa ve Fen Dergisi, 1(2), 132-139.

Manley, M.G., Engelbrecht, M.L., Williams, P.C. and Kidd, M. (2009). Assessment of variance in the measurement of hectoliter mass of wheat, using equipment from different grain producing and exporting countries. Biosystems Engineering, 103(2), 176-186.

Menderis, M., Atli, A., Köten, M. and Kiliç, H. (2008). gluten indeks değeri ve yaş gluten/protein oranı ile ekmeklik buğday kalite değerlendirilmesi. Harran Üniversitesi Ziraat Fakültesi Dergisi, 12(3), 57-64.

Migliorini, P., Spagnolo, S., Torri, L., Arnoulet, M., Lazzerinic, G. and Ceccarelli, S. (2016). Agronomic and quality characteristics of old, modern and mixture wheat varieties and landraces for organic bread chain in diverse environments of northern Italy. European Journal Agronomy, 79, 131-141.

Modenes, A.N., Silva, A.M.D. and Trigueros, D.E.G. (2009). Rheological properties evaluation of stored wheat. Food Science and Technology (Campinas), 29(3), 508512. 20612009000300008

Mohsenin, N.N. (1986). Physical properties of plant and animal materials. Gordon and Breach Science, Newyork, pp. 891.

Mutlu, A. and Taş, T. (2020). Türkiye'de yetiştirilen bazı ekmeklik buğday çeşitlerinin yarı kurak iklim koşullarında (T. aestivum L.) kalite özellikleri ile verim ve verim unsurlarının incelenmesi. Avrupa Bilim ve Teknoloji Dergisi, 19, 344-353.

Özkaya, H. and Özkaya, B. (2005). Öğütme Teknolojisi. Gıda Teknolojisi Derneği Yayınları No:30, Ankara.

Pekmez, H. (2018). Physicochemical characteristics and flourgraph properties of wheat varieties (Triticum aestivum L.) used in flat bread (Gaziantep pita). Cyta-Journal of Food, 16(1), 965-971.

Protic, R., Miric, M., Protic, N., Jovanovic, Z. and Jovin, P. (2007). The test weight of several winter wheat genotypes under various sowing dates and nitrogen fertilizer rates. Romanian Agricultural Research, 24, 43-36.

Şahin, M., Göçmen Akçacık, A., Aydoğan, S., Demir, B., Mecitoğlu Güçbilmez, Ç., Hamzaoğlu, S., Gür, S., Yıldırım, T. (2020). Ekmeklik buğday (Triticum aestivum) genotiplerinin gluten kalitesinin glutopik cihazı ile değerlendirilmesi. Harran Tarım ve Gıda Bilimleri Dergisi, 24 (2), 151-164. DOI: 10.29050/harranziraat.657208

Şahin, M., Göçmen-Akçacık, A., Aydoğan, S. and Yakışır, E. (2016). Orta Anadolu sulu koşullarında bazı kışlık ekmeklik buğday genotiplerinin verim ve kalite performanslarının belirlenmesi. Tarla Bitkileri Merkez Araştırma Enstitüsü Dergisi, 25(1), 19-23. DOI: 10.21566/tarbitderg. 279721

Şanal, T., Olgun, M., Erdoğan, S., Pehlivan, A., Yazar, S., Budak-Başçiftçi, Z., Kutlu, I. and Ayter, N.G. (2012). Quality analysis of Turkey in bread wheat by interpolation technique I. Red bread wheat. Biological Diversity and Conservation, 5(3), 69-75.

Tabatabaeefar, A. (2003). Moisture-dependent physical properties of wheat. International Agrophysics. 17, 207-211.

Tayyar, Ş. (2010). Variation in grain yield and quality of romanian bread wheat varieties compared to local varieties in northwestern turkey. Romanian Biotechnological Letters, 15(2), 5189-5196.

Troccoli, A. and di Fonzo, N. (1999). Relationship between kernel size features and test weight in Triticum durum. Cereal Chemistry, 76(1), 45-49. https://doi.org/10.1094/CCHEM.1999.76.1.45

Türk, S. (2013). Göller bölgesi'nde bulunan un fabrikaları tarafından kullanılan yerel ve ithal ekmeklik buğdayların fiziksel, kimyasal ve teknolojik özellikleri ile ekmeklik kalitelerinin belirlenmesi. Süleyman Demirel Üniversitesi. Fen Bilimleri Enstitüsü, Yüksek Lisans Tezi, Isparta, 101s.

Ünal, S. (2002). Buğdayda Kalitenin Önemi ve Belirlenmesinde Kullanılan Yöntemler. Hububat Ürünleri Teknolojisi ve Sergisi, 3-4 Ekim 2002, Gaziantep, s.25-37.

Ünal, S. (2003). Buğday ve un kalitesinin belirlenmesinde uygulanan yöntemler. Nevşehir ekonomisinin sorunları ve çözüm önerileri: Un sanayi örneği, Nevşehir Ekonomi Sempozyumu 1, 27-28 Haziran 2003, 15-29.

Williams, P. C., Nakoul, H. and Singh, K. B. (1983). Relationship between cooking time and some physical characteristics in chickpeas (Cicer Arietinum L.). Journal of the Science of Food and Agriculture, 34(5), 492-496.

Yağdı, K. (2004). Bursa koşullarında geliştirilen ekmeklik buğday (Triticum aestivum L.) hatlarının bazı kalite özelliklerinin araştırılması. Uludağ Üniversitesi. Ziraat Fakültesi Dergisi, 18(1), 11-23.

Yıldırım, A. and Atasoy, F.A. (2020). Quality characteristics of some durum wheat varieties grown in 
Southeastern Anatolia Region of Turkey (GAP). Harran Journal of Agricultural and Food Sciences, 24(4),

420-431.

https://doi.org/10.29050/harranziraat.738505

Youssef, M. M. (1978). A study of factors affecting the cook ability of faba beans (Vicia faba L). Ph.D. Thesis,
College of Agricultural University of Alexandria, Alexandria, Egypt.

Zilic, S., Barac, M., Pesic, M., Dodig, D. and Ignjatovi-Micic, D. (2011). Characterization of proteins from grain of different bread and durum wheat genotypes. Int. J. Mol. Sci., 12, 5878-5894. doi:10.3390/ijms12095878 